\title{
Corona: Prevention and Awareness is a Strategic Choice
}

\author{
Prof. Saleha Y. M. Alakilli*
}

Professor of Genetic Engineering and Molecular Biotechnology, College of Applied Medical Sciences, Jouf University, Kingdom of Saudi Arabia

DOI: $10.36348 /$ sjbr.2020.v05i04.001

| Received: 03.04.2020 | Accepted: 11.04.2020 | Published: 14.04.2020

*Corresponding author: Prof. Saleha Y. M. Alakilli

Copyright @ 2020: This is an open-access article distributed under the terms of the Creative Commons Attribution license which permits unrestricted use, distribution, and reproduction in any medium for non-commercial use (NonCommercial, or CC-BY-NC) provided the original author and source are credited.

Epidemic diseases are the most guarded enemy for humans since ancient times as they have a destructive force capable of fighting the inhabitants of an entire city as it was known about the plague disease, they are just more than threats throughout the ages, and a careful look at the history of many epidemics and the subsequent breathless research in a race With time to find the effective serum to eliminate the epidemic.

It is perhaps very important to focus on the challenge of corona (corona's disease) that has been discovered and dealt with some cases of it. Accordingly, we, as scholars, researchers, writers and thinkers at Al-Jouf University and other edifices of science, thought, knowledge and advancement, have had such an event that worries many countries, which called on them to raise the maximum levels of readiness for all quarantine departments, entry points and all hospitals practicing in any emergency. We know very well the role that our rational government plays in taking all security, preventive and curative obligations and precautions for all diseases and epidemics, and it is incumbent upon all of us to contribute to everything that would benefit our country and guarantee the safety of citizens, residents, and visitors of pilgrims and pilgrims, and that we have a clear role in That's all according to his specialty.

Corona virus affects the upper respiratory tract, causing some respiratory diseases and may include acute pneumonia. But there is evidence to prove that it may penetrate the body, affect the central nervous system and cause long-term neurological disorders. In previous years, seven strains of the Coruna virus were discovered, and more recently the Corona Virus (2019-nCoV, Corona Wuhan).

Proceeding from the fact that the most important alphabet of safety and prevention of any disease is identifying its cause, the Corona virus in the Middle East belongs to one of the large viral families known to affect humans and animals and is called Coronaviridae. The genetic material of this virus is characterized by a single positive polar thread called RNA. Corona is a Latin word meaning "crown," as the virus takes the form of a crown when viewed in an electron microscope. The length of the virus ranges between 120-150 nanometers, and the size of the genetic material ranges between 27-32 thousand nitrogenous bases.

Coronavirus affects the upper respiratory tract, causing some respiratory diseases and may include acute pneumonia. But there is evidence to prove that it may penetrate the body, affect the central nervous system and cause long-term neurological disorders. In previous years, seven strains of the Coruna virus were discovered, and more recently the Corona Virus (2019. nCoV, Corona Wuhan).

Proceeding from the fact that the most important alphabet of safety and prevention of any disease is identifying its cause, the Corona virus in the Middle East belongs to one of the large viral families known to affect humans and animals and is called Coronaviridae. The genetic material of this virus is characterized by a single positive polar thread called RNA. Corona is a Latin word meaning "crown," as the virus takes the form of a crown when viewed in an electron microscope. The length of the virus ranges between 120-150 nanometers, and the size of the genetic material ranges between 27-32 thousand nitrogenous bases.

This fact takes us directly to alternative steps as urgent solutions pending the arrival of scientists to produce vaccines capable of eliminating this epidemic, and we all know that the most important protocols of immunology and vaccines are that no vaccine can be discovered and made overnight, not to mention vital experiments on animals and then humans to prove The effectiveness and safety of the vaccine, which may take 
a long time, may reach for years, and here comes the issue that was the cause of what caused by these epidemics of disasters, it was possible to reduce their damages to safe levels of their devastating effects, namely prevention and awareness, as they seem to be a strategic solution to the extent of Seen as a drug alternative and a viable and perhaps it is useful to remember the old adage (an ounce of prevention is better than Guentaralaj).

Lastly, I see that from here comes the role of the government and civil society institutions in dealing professionally and professionally and starting the establishment of high committees from the relevant ministries to coordinate these programs in an organized manner and organizing national awareness-raising and voluntary campaigns to introduce the disease and optimal methods of prevention and the publication of programs of international systems in measures to combat epidemic diseases, and to carry out campaigns targeting Citizens, residents, and places such as hospitals, schools, universities, neighborhood centers, airports, ports, and human density sites along with the formation of volunteer teams at the neighborhood level (if possible) or cities consisting of specialists in this field and holistic students $\mathrm{T}$. medicine, nursing and health sciences colleges, and university professors in all disciplines that benefit in this area, in addition to broadcast media campaigns send messages of awareness and reassurance so that the movement does not turn this into a panic may destroy these efforts blessed God forbid. Finally, we ask God to protect us and our country from all harm. 